\title{
Tolerance-Inducing Strategies in Islet Transplantation
}

\author{
Sumantha Bhatt, ${ }^{1}$ John J. Fung, ${ }^{2}$ Lina Lu, ${ }^{1,2}$ and Shiguang Qian ${ }^{1,2}$ \\ ${ }^{1}$ Department of Immunology, Lerner Research Institute, Cleveland Clinic, Cleveland, OH 44195, USA \\ ${ }^{2}$ Department of General Surgery, Transplant Center, Digestive Disease Institute, Cleveland Clinic, Cleveland, OH 44195, USA
}

Correspondence should be addressed to Shiguang Qian, qians@ccf.org

Received 15 December 2011; Accepted 8 March 2012

Academic Editor: A. N. Balamurugan

Copyright ( 2012 Sumantha Bhatt et al. This is an open access article distributed under the Creative Commons Attribution License, which permits unrestricted use, distribution, and reproduction in any medium, provided the original work is properly cited.

\begin{abstract}
Allogeneic islet transplantation is a promising approach for restoring normoglycemia in type 1 diabetic patients. Current use of immunosuppressive therapies for management of islet transplant recipients can be counterintuitive to islet function and can lead to complications in the long term. The induction of donor-specific tolerance eliminates the dependency on immunosuppression and allows recipients to retain responses to foreign antigens. The mechanisms by which tolerance is achieved involve the deletion of donor-reactive $\mathrm{T}$ cells, induction of T-cell anergy, immune deviation, and generation of regulatory $\mathrm{T}$ cells. This review will outline the various methods used for inducing donor-specific tolerance in islet transplantation and will highlight the previously unforeseen potential of tissue stromal cells in promoting islet engraftment.
\end{abstract}

\section{Introduction}

Diabetes mellitus is a disease characterized by metabolic abnormalities and the onset of hyperglycemia, which results from dysregulation of insulin. Insulin promotes the entry of glucose from the blood into the tissues. Diabetes affects approximately 25.8 million people of all ages, with the prevalence rising with age. Long-term complications of diabetes include nephropathy, retinopathy, neuropathy, and atherosclerosis [1]. The type II variant, or noninsulin-dependent form, arises from a resistance to insulin or inadequate production of insulin by the pancreatic $\beta$ islets, eventually leading to islet dysfunction and desensitization to glucose. Type II diabetes accounts for $90-95 \%$ of all diagnosed cases of diabetes [1]. The current management for type II diabetes involves a change in lifestyle-weight loss and dietary modifications - and administration of glucose reducing agents. Type I diabetes, the more severe form of diabetes, affects $5 \%$ of the population [1] and results from autoimmune destruction of the pancreatic $\beta$ islets. Since the islets fail to produce insulin altogether, the only treatment options for type I diabetes are exogenous delivery of insulin and pancreas or islet transplantation.

Despite improvements in the administration of insulin delivery and insulin supplying devices, maintenance of adequate and steady glucose levels with exogenous insulin therapy alone can be challenging and can cause episodes of hypoglycemia. Diabetic patients with suboptimal control of glycemia ultimately develop long-term complications. Currently the only real "cure" for type I diabetes is transplantation of the pancreas or isolated islets, which would result in insulin production closer to physiological conditions.

However, pancreas transplantation is generally considered only for severe, late-stage diabetics and is a significant surgical procedure requiring extensive immunosuppression [2-4]. Islet transplantation is, therefore, a more feasible alternative to pancreas transplantation. In comparison, islet transplantation has lower risks of morbidity and mortality and greater opportunities for in vitro manipulations of islets to optimize engraftment. The concept of transplanting pancreatic fragments to reverse diabetes was first proposed by the English surgeon Watson Williams in 1893 [5]. However, lack of knowledge about immune rejection and immunosuppression at the time prevented progress [2]. It was not until 1967 that Lacy and Ballinger demonstrated the first real advancement in islet transplantation. Using a rodent model in which recipients of islet allografts were induced to develop type I diabetes by administration of streptozotocin (STZ), mimicking autoimmune destruction of the pancreatic islets, Kemp et al. demonstrated that pancreatic islet cell 
transplants could restore metabolic control and prevent long-term complications [6].

Translation from rodent to larger animal and human models had been hampered by difficulties in islet isolation from the pancreas, the lack of quality of isolated islets, and route of administration [7, 8]. The development of an automated method for human islet cell processing by Ricordi et al. in 1986 [9] and the discovery that islet clusters could be heterotopically implanted into the liver contributed to the first successful allogeneic islet transplantation in humans in 1989 by Lacy et al. [6, 10, 11]. Nevertheless, success rates remained low with only $10 \%$ of patients achieving insulin independence for greater than a year and demonstrating islet allograft rejection and recurrence of autoimmunity. Poor clinical outcomes were attributed to insufficient numbers of islets being transplanted and an ineffective immunosuppression regimen [12].

\section{Immune Response to the Graft}

The alloresponse is largely a T-cell-mediated response to the major histocompatibility complex molecules (MHCs) on the surface of donor tissues. Antigen presenting cells (APCs), such as dendritic cells (DCs), process and present donor peptides and molecules through MHCs to recipient $\mathrm{T}$ cells by the indirect pathway. Additionally, recipient $\mathrm{T}$ cells can recognize donor antigen directly on the surface of infiltrating donor-derived APCs through the direct pathway. T-cell receptors (TCR) on the surface of the recipient $\mathrm{T}$ cells recognize the peptide-MHC complex, initiating signaling cascades and activation of the $\mathrm{T}$ cells. In addition to this primary signal, additional interactions through costimulatory molecules on the T cells and APCs are required for full activation of the $\mathrm{T}$ cells. Upon activation, the $\mathrm{T}$ cells promote a series of proinflammatory events and initiate the activation of other cell types resulting in recruitment of leukocytes and humoral factors to the graft. The effector response includes the production of the cytokines IFN- $\gamma$ and IL- 2 by type 1 helper (Th1) $\mathrm{CD}^{+} \mathrm{T}$ cells, the cytotoxic factors granzyme and perforin by $\mathrm{CD} 8^{+} \mathrm{T}$ cells, and alloantibodies (Abs) by $\mathrm{B}$ cells [13].

\section{Pitfalls of Immunosuppression}

Current immunosuppressive therapies target $\mathrm{T}$ cells since they are the main culprits in rejection. Previously, the standard protocol for immunosuppression for islet transplantation consisted of a combination of calcineurin inhibitors (tacrolimus and cyclosporine), purine analogs (mycophenolate mofetil), and corticosteroids. Many of these agents proved to be diabetogenic, impairing insulin secretion, and lethal to the islets [14]. The advent of the Edmonton protocol in 1999 was a significant step in the field of islet transplantation.

The Edmonton protocol utilized a steroid-free therapy based on low-dose sirolimus, tacrolimus, and daclizumab (a humanized anti-IL-2 receptor $\alpha \mathrm{mAb}$ ). Furthermore, the protocol administered two infusions of islets from different donors to increase chances of engraftment. All 7 patients involved in the trial demonstrated insulin independence beyond 1 year $[15,16]$. Despite the success of rapamycinbased therapies, they have their own shortcomings including increased risk of hyperlipidemia, hypertension, and pneumonia [15]. Work by Monti et al. reported that patients conditioned under the Edmonton protocol receiving infusion of cadaveric islets developed lymphopenia and displayed elevated serum levels of homeostatic cytokines, leading to the expansion of autoreactive cells [17].

While the results of multiple center clinical trials demonstrated that the protocol can provide short-term insulin independence and reduce incidences of acute rejection, the patients regressed back to insulin dependency, and graft function was lost in several patients within 5 years [18]. Chronic administration of immunosuppression of any kind will eventually lead to risk of infection, malignancies, and drug toxicity [19]. Maintenance immunosuppression can, therefore, be detrimental rather than beneficial to transplant recipients. Side effects of immunosuppression often outweigh the benefits of islet transplantation.

The risks associated with immunosuppressive agents prompted investigation into tolerance inducing therapies, with the goal being to achieve indefinite graft survival without dependency on long-term immunosuppression while preserving host immunity to other alloantigens. Tolerance induction has been challenging in both large animal and human models due to the complex nature of the alloresponse. Tolerance at both the central and peripheral stages involves clonal deletion of alloreactive T-cells, T cell anergy, immune deviation, and induction of regulatory $\mathrm{T}$ cells.

\section{Central Tolerance}

Central tolerance refers to lack of responsiveness to self through deletion of self-reactive $\mathrm{T}$ cells in the thymus-the site of T-cell maturation and selection [20]. Donor-specific tolerance can be achieved using strategies similar to those used for preventing autoimmunity. Intrathymic tolerance (IT) can be induced by intrathymic inoculations of recipient APCs pulsed with allopeptides. Alloantigens, when presented in the context of self-APCs result in donor-specific unresponsiveness and promote tolerance. However, the clinical applications of the IT model face many challenges as it is an invasive technique and may have limited potential in adults, since the thymus involutes with age, compromising the tolerance process [21,22].

An alternative and perhaps more effective method for achieving central tolerance involves the generation of hematopoietic chimerism, which is developed through bone marrow (BM) transplantation. Prospective transplant recipients are conditioned with total body irradiation (TBI) or partial myeloablation prior to $\mathrm{BM}$ transplantation in order to make room for the transplanted bone marrow. BM cell transplantation enables the reconstitution of the recipient hematopoietic compartment with donor hematopoietic stem cells. Donor-reactive T cells are then deleted through central 
regulation and maintained by peripheral mechanisms. The use of TBI for prolonging islet allograft survival was originally proposed by Britt et al. [23] and later shown by other groups to prevent the onset of diabetes in nonobese diabetic (NOD) mice [24]. Though combined islet and hematopoietic cell transplant seems promising, the inherent risks associated with the process have limited its applications. TBI or myeloablation prior to receipt of the BM increases the risk of infection and malignancies. Additionally, BM transplantation is met with the risk of graft versus host disease (GVHD) $[25,26]$. Mixed allogeneic chimerism is emerging as a safer method to fully allogeneic chimerism. Mixed chimerism can be achieved in allogeneic BM recipients conditioned with sublethal total body irradiation with the aid of costimulatory blockade or anti-CD4 and antiCD8 monoclonal (m)Abs [27-29]. NOD mice receiving nonmyeloablative conditioning accepted allogeneic islets and displayed a reversal of autoimmunity, suggesting successful establishment of mixed chimerism [30]. Similarly, NOD mice that received low-dose irradiation, cyclophosphamide (CY), and two intravenous infusions of BM from WT mice showed high levels of donor-cell chimerism and effectively eliminated host donor-reactive lymphocytes after transfer of splenocytes from overtly diabetic NOD mice [31, 32]. BM infusion at the time of islet transplantation may, therefore, be used to induce donor-specific tolerance to islet allografts.

\section{Tolerance through T-Cell Depletion Strategies}

Another strategy in promoting tolerance involves the depletion of alloreactive $\mathrm{CD}^{+}$and $\mathrm{CD}^{+}{ }^{+} \mathrm{T}$ cells prior to transplantation. Depletion of alloreactive T cells would promote a hyporesponsive environment and peripheral mechanisms of anergy, thus driving the shift towards tolerance $[33,34]$. Depletion can be achieved through TBI, lymphocyte depleting Abs, and pharmaceutical agents. Anti-CD $3 \mathrm{mAb}$ has been used for development of mixed chimerism in murine NOD models with few side effects, achieving the same results as myeloablation while bypassing the risk of $\operatorname{GVHD}[35,36]$. Anti-CD3 mAb is proposed to downmodulate the TCR complex, induce apoptosis of alloreactive $\mathrm{T}$ cells, increase production of the immunoregulatory cytokine TGF- $\beta$, and promote the development of regulatory T cells $[37,38]$. AntiCD3 is effective in inducing tolerance in models of both syngeneic and allogeneic islet transplantation, enabling longterm engraftment $[34,39]$. Antithymocyte globulin (ATG) is also a potent inducer of T-cell depletion. Its mechanisms of action are poorly understood, though. Administration of ATG alone or in combination with other agents prolonged allograft survival in various models [40-43]. Islet allograft survival was significantly improved in a nonhuman primate model with administration of ATG and the B-cell-depleting CD20 mAb, rituximab [44]. Taken together these findings suggest that lymphoid-depleting agents may not be effective as a monotherapy but may be useful in combination with other tolerance-inducing therapies.

\section{Tolerance Induction through Costimulatory Blockade}

Tolerance can also be achieved by interfering with costimulatory interactions to inhibit the secondary signal required for full T-cell activation. Suboptimal signaling renders the cells anergic. The B7-CD28 pathway is a key pathway in Tcell activation, survival, and function. Blockade of the B7 (CD80, CD86) receptor on APCs with CD28 on T cells modulates the immune response. In rodent models, B7-CD28 blockade through administration of inhibitory CTLA4-Ig led to prolonged allograft survival and tolerance [45-48]. In nonhuman primates, however, CTLA-Ig treatment alone led to moderate improvements in allograft survival but failed to induce tolerance [47-49].

Similar findings have been reported with CD40-CD154 blockade. Ligation of the CD40 receptor on APCs with CD40 ligand (CD154) on T cells enhances TCR signaling and effector responses [50, 51]. CD154-deficient mice displayed impaired antigen-specific T-cell responses and priming. Coadministration of anti-CD154 mAb and inactivated donor lymphocytes resulted in long-term survival of islet allografts in an STZ-induced rodent model and nonhuman primate models with pancreatectomy [7, 52, 53]. AntiCD154 mAb downregulated CD28 on donor lymphocytes, thereby inhibiting CD28-CD80 interactions between donor APCs and recipient T cells [54]. Anti-CD154 mAb treatment has been shown to result in "indefinite" survival in islet, BM, and cardiac allograft models [53, 55-57].

Whether true tolerance can be achieved with anti-CD154 $\mathrm{mAb}$ alone or in combination with $\mathrm{BM}$ transplantation, donor-specific transfusion (DST), or conventional immunosuppression is debatable. Anti-CD154 mAb therapy is met with mixed results. Kenyon et al. reported that rhesus monkeys treated with the humanized anti-CD154 mAb (hu5c8) prior to transplantation with periodic maintenance therapy achieved long-term survival and improved function of intrahepatic islet allografts with little to no side effects [7]. In contrast, Kirk et al., using a similar regimen, found that while hu5c8 therapy prevented acute renal allograft rejection in rhesus monkeys, recipients developed donor-specific Abs and showed signs of chronic allograft nephropathy [58]. A similar result has been reported by Azimzadeh et al. using a primate cardiac allograft model [59]. Although anti-CD154 mAb therapy may allow for the manipulation of donorspecific responses and assist in the induction of tolerance, the consequences of administering anti-CD154 mAb need to be evaluated further. There are strong indications that antiCD154 mAb therapy results in thromboembolic complications in nonhuman primate models [60]. Discrepancies in outcomes may be due to timing of administration, dosage, duration, and dependent on the animal model.

\section{DCs in Tolerance}

DCs play a critical role in provoking the immune response by mediating the uptake, processing, and presentation of antigen from the microenvironment to naive $\mathrm{T}$ cells in 
the secondary lymphoid tissues. However, DCs also act as regulators in the thymus and periphery by eliminating selfreactive $\mathrm{T}$ cells and preventing autoimmunity [21]. Therefore, DCs may be key to achieving central and peripheral tolerance by helping shape the immune response. The immunogenic versus tolerogenic nature of DCs is dependent on the maturation of the DCs and the subset. Manipulation of DCs may, therefore, serve as a therapeutic tool in the design of tolerogenic regimens $[61,62]$. Murine DC subsets are characterized and categorized based on their surface markers and origin, such as myeloid DCs $\left(\mathrm{CD} 11 \mathrm{c}^{+} \mathrm{CD} 8 \alpha^{+}\right.$, CD $11 c^{+} \mathrm{CD} 8 \alpha^{-}$), plasmacytoid (p)DCs (CD $11 c^{-} \mathrm{B} 220^{+} \mathrm{Gr}-$ $\left.1^{+}\right)$, and Langerhans cell-derived DCs from the epidermis $\left(\mathrm{CD} 11 \mathrm{c}^{-}\right)$. Human DCs fall primarily into two categories: monocytes and pDCs $\left(\mathrm{CD} 4^{+} \mathrm{CD} 8^{-} \mathrm{CD} 11 \mathrm{c}^{-}\right)$. Differences in murine and human DC surface markers make comparisons difficult [63].

Whereas mature myeloid DCs upregulate MHC class II and the costimulatory molecules CD40, CD80, and CD86, immature DCs downregulate these markers and are potent inhibitors of allospecific T-cell responses [64]. The lack of stimulatory molecules allows immature DCs to induce antigen specific hyporesponsiveness in $\mathrm{T}$ cells [65]. Immature DCs also vary in their stimulatory activity. CD11b ${ }^{+} \mathrm{CD} 8 \alpha^{-}$ DCs induce a Th2 phenotype (IL-4, IL-5, IL-10, and IL13), while $\mathrm{CD} 11 \mathrm{~b}^{-} \mathrm{CD} 8 \alpha^{+}$DCs induce a Th1 phenotype (IL-2 and IFN- $\gamma$ ) through secretion of IL-12 [63, 66]. In addition to skewing the Th1/Th2 profile, tolerogenic DCs have been shown to promote allograft acceptance by deletion and anergy of alloreactive $\mathrm{T}$ cells and induction of donorspecific regulatory $\mathrm{T}$ (Treg) cells [67-69].

The ability of tolerogenic DCs to mediate anergy and proliferative arrest of alloreactive $\mathrm{T}$ cells has been demonstrated by Munn et al. pDCs produce indoleamine 2,3dioxygenase (IDO), which catabolizes the essential amino acid L-tryptophan, and triggers the integrated stress pathway within antigen specific $\mathrm{T}$ cells and suppresses their proliferation and function [70]. The exact mechanism by which these tolerogenic DCs inhibit alloreactive $\mathrm{T}$ cells is not well understood but is thought to involve the activation of the general control nondepressible-2 (GCN2) kinase pathway. The GCN2 pathway is activated in response to an accumulation of uncharged tRNAs that results from amino acid deprivation [71]. Transfer of tolerogenic IDO producing immature DCs from primary tolerant recipients into murine cardiac allograft recipients enhanced allogeneic T cell apoptosis and Treg-cell development resulting in prolonged graft survival [67]. Ochando et al. showed that treatment with DST and anti-CD154 mAb prompted pDCs to migrate to the allograft and subsequently induced Treg development in the lymph nodes. Furthermore, pDCs isolated from tolerogenic mice promoted $\mathrm{CD} 4^{+} \mathrm{CD} 25^{-}$Foxp $3^{-} \mathrm{T}$ cells to convert into $\mathrm{CD} 4^{+} \mathrm{CD} 25^{+}$Foxp $3^{+}$Treg cells in vitro [72].

DC maturation can be limited through addition of cytokines (IL-10 and TGF- $\beta$ ) and costimulatory blockade $[73,74]$. In mice, BM cells cultured in the presence of granulocyte macrophage colony-stimulating factor (GM-CSF) alone tended to acquire an immature phenotype-expressing low levels of MHC class II and costimulatory molecules.
In contrast, addition of IL-4 to the GM-CSF culture led to DC maturation and high levels of MHC class II, CD40, CD80, and CD86 expression [75-77]. DCs can be restricted to an immature state through pharmacological interventions as well. In vitro, rapamycin conditioned BM-derived DCs suppressed the development of alloreactive $\mathrm{CD} 4^{+} \mathrm{T}$ cells but allowed for the proliferation and functioning of Tregs [78]. Lutz et al. examined the tolerogenic potential of immature myeloid DCs and found that the transfer of these immature myeloid DCs induced a state of T-cell unresponsiveness and resulted in a significant improvement in cardiac allograft survival [75].

In addition to extrinsic influences, DC maturation is also governed by NF- $\kappa \mathrm{b}$ signaling. NF- $\kappa \mathrm{b}$ regulates expression of MHCs and costimulatory molecules. Lu et al. inhibited NF- $\kappa$ b activity within DCs by constructing a decoy doublestranded oligodeoxynucleotide (ODN) that selectively inhibited expression of costimulatory molecules while permitting the expression of MHCs, thus preventing DC maturation. Genetic engineering of DCs allows for expression of molecules that play a role in the inhibition of T-cell responses. Administration of DCs deficient in NF- $\kappa$ b activity prevented the onset of diabetes in NOD mice [79]. Recipients of virally transduced DCs expressing CTLA4-Ig, IL-10, or FasL displayed improved pancreatic islet and cardiac allograft survival [80-83]. The therapeutic potential of these engineered DCs is limited by the fact that the cells may become activated or mature in vivo through exposure to the virus and proinflammatory stimuli [80].

\section{Myeloid-Derived Suppressor Cells (MDSCs) in Tolerance}

MDSCs are emerging as important regulators of tolerance. Originally identified for their role as suppressors in cancer $[84,85]$, MDSCs are comprised of heterogeneous myeloid cell populations: subsets of DCs, macrophages, and granulocytes. MDSCs in mice are characterized based on expression of the markers CD11b, Gr-1, Ly6C, and Ly6G. MDSCs can be divided even further by their nuclear morphology as mononuclear, monocytic MDSCs $\left(\mathrm{CD} 11 \mathrm{~b}^{+} \mathrm{Gr}-\right.$

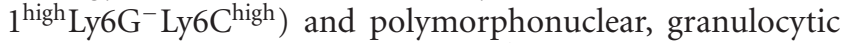

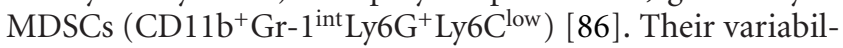
ity can even be extended to their function and production of immunosuppressive components arginase-1 (Arg-1), inducible nitric oxide synthase (iNOS), and reactive oxygen species (ROS), with suppressive function depending on the environment and pathological condition [87-89]. MDSCs make up a relatively small proportion in healthy mice but expand and accumulate in the lymphoid tissue of tumor bearing mice, remaining in an immature state and inhibiting antitumor responses $[90,91]$. The generation and expansion of MDSCs is dependent on inflammatory cues [92, 93]. The inflammatory molecules vascular endothelial growth factor (VEGF) and GM-CSF have been linked to the accumulation of MDSCs [94, 95]. Additional proinflammatory cytokines IL- $1 \beta$ and IL- 6 have been shown to contribute to the development of MDSCs. IL- $1 \beta$ secreting tumors had greater 
accumulation of MDSCs with improved lifespan resulting in aggressive tumor growth [96-98].

The ability of MDSCs to suppress T-cell responses and expand Treg cells has been demonstrated in various models of autoimmunity, infection, and cancer [99-101]. The mechanisms by which MDSCs impart their suppressive effect include production of iNOS and arginase-1. Arginase1 depletes L-arginine resulting in downregulation of the TCR $\zeta$ chain and inhibition in production of cell cycle regulator proteins $[102,103]$. iNOS promotes phosphorylation of the Janus kinase 3 and STAT5 pathway and inhibits MHC class II expression and T-cell proliferation [104106]. MDSCs also produce ROS and peroxynitrates, which inhibit protein tyrosine phosphorylation through nitration of tyrosine residues $[88,107]$. Increased production of these factors was observed in tumor models and related to T-cell unresponsiveness [108].

As suggested in tumor models, MDSCs may be useful in transplant settings by suppressing alloreactive $\mathrm{T}$ cell responses and prolonging graft survival. In a murine kidney allograft model, Dugast et al. demonstrated that recipients with long-term surviving grafts exhibited an accumulation of $\mathrm{CD}^{-}{ }^{-} \mathrm{MHC} \mathrm{II}^{-} \mathrm{CD} 11 \mathrm{~b}^{+} \mathrm{CD} 80 / 86^{+}$cells in the blood and graft. Isolation and characterization of the cells revealed myeloid-like morphology. These cells showed strong suppressive activity against activated $\mathrm{T}$ cells, with suppressive activity related to the increased number of cells and dependent on production of iNOS. The phenotypic and functional analysis of these cells fits the criteria for MDSCs. Inhibition of the MDSC suppressor molecule iNOS by aminoguanidine resulted in rejection of kidney allografts [109]. MDSCs also have implications in skin transplant models. Heme oxygenase-1 (HO-1) secreting MDSCs facilitated tolerance in recipients of skin allografts through T-cell suppression and IL-10 production [110]. Our group has recently shown that cotransplantation of MDSCs with islet allografts reduces $\mathrm{CD}^{+}$effector $\mathrm{T}$-cell responses and results in the expansion of antigen specific Tregs in the draining lymph nodes (dLNs), spleen, and peripheral blood, translating to markedly improved islet allograft survival. MDSC-mediated suppressor functions were dependent on the inhibitory B7H1 (PD-L1)-PD1 pathway. The protective effect imparted by Tregs was negated in recipients receiving B7- $\mathrm{H1}^{-/-}$MDSCs. Frequencies of $\mathrm{CD}^{+} \mathrm{Foxp}^{+}$cells were markedly reduced in all compartments in $\mathrm{B} 7-\mathrm{H}^{-/-}$MDSC recipients. Direct evidence for the role of $\mathrm{B} 7-\mathrm{H} 1$ in MDSC-induced Treg development was demonstrated through in vitro coculture of donor BALB/C T cells with DCs or MDSCs from WT or B7$\mathrm{H} 1^{-/-}$MDSCs. WT MDSCs expanded Foxp $3^{+}$cells, whereas MDSCs deficient in B7-H1 exhibited reduced capacity for Treg induction. Further evidence was shown in B6 mice intravenously injected with OVA-specific $\mathrm{CD}^{+}{ }^{+} \mathrm{T}$ cells with subsequent footpad injection of OVA-pulsed WT or B7$\mathrm{H}^{-/-}$MDSCs. Examination of the popliteal LNs showed an increase in the frequency of $\mathrm{CD} 4^{+} \mathrm{Foxp}^{+}$cells in recipients of OVA-pulsed WT MDSCs compared to recipients of OVApulsed B7-H1 $1^{-/-}$MDSCs. Therefore, it appears that MDSCs require $\mathrm{B} 7-\mathrm{H} 1$ to exert their immunoregulatory activity and to induce Tregs $[111,112]$.

\section{Tregs in Tolerance}

The presence of $\mathrm{CD} 4^{+} \mathrm{CD} 25^{+} \mathrm{Foxp} 3^{+}$regulatory $\mathrm{T}$ cells is correlated with improved graft outcomes and tolerance [113-116]. Tregs act as surveillance for the immune system, and depletion of Tregs results in lymphoproliferation and autoimmune syndrome [117-119]. Biopsies taken from grafts of tolerant recipients had greater infiltration of Tregs compared to those from rejecting grafts [120]. While Treg cells only make up $5-10 \%$ of the mature T-cell population, they are potent in numbers [121]. Lymphodepletional therapies and costimulatory blockades alone can do little in terms of promoting tolerance; therefore, strategies that promote Treg cells and their functions will improve chances of engraftment. Unfortunately, many immunosuppressive agents, especially those targeting the IL-2 receptor and IL-2, inhibit Treg development and function since IL-2 signaling is critical to $\mathrm{T}$ cell survival and proliferation [122]. The ideal scenario would minimize immunosuppressive therapy and focus on expanding the endogenous Treg population or generation of antigen-specific Tregs, thereby inducing tolerance without the need for immunosuppression.

There is evidence that apoptotic cells have the ability to influence Treg development by way of DCs [123]. Apoptotic cells suppress inflammatory responses by emitting inhibitory signals to DCs and other phagocytes. Adopt transfer of donor apoptotic cells imparted an immature phenotype on DCs, which in turn inhibited $\mathrm{CD}^{+}{ }^{+} \mathrm{T}$ cell activation and IL2 and IFN- $\gamma$ production. Combination with CD40-CD154 blockade led to prolonged cardiac allograft survival through induction of Tregs [124].

It is speculated that Tregs impart their suppressive function through direct interactions with cells (engagement with CTLA4-Ig), production of soluble factors and inhibitory cytokines TGF- $\beta$ and IL-10, and cytokine deprivation [125, 126]. Zhang et al. [127] provided mechanistic insight into how Tregs exert their suppressive effect using an islet allograft model. Tregs in the blood migrated to the allograft through the guidance of the chemokines CCR2, CCR4, and CCR5. Upon activation, they traveled to the dLNs where they inhibited DC migration and antigen-specific T-cell migration and response in the dLNs and islet allografts [127]. Similar observations were made by Golshayan et al. Alloantigen specific Tregs were expanded in vitro and maintained their suppressive function in vivo. When transferred into recipients of skin allografts, they trafficked to the secondary lymphoid organs and accumulated in the graft dLNs and within the allograft itself. The donor-specific Tregs delayed graft rejection in the absence of immunosuppression. Tregs infiltrated skin allografts early on in the immune response and suppressed rejection by inhibiting alloreactive T-cell responses. In the presence of Tregs, $\mathrm{CD} 4^{+} \mathrm{T}$ cells produced far less IFN- $\gamma$ and did not accumulate in the secondary lymphoid tissues [113]. The suppressive features of Tregs make them candidates for therapeutic use in islet transplantation.

The differential effects of immunosuppressive therapies on Treg development make it difficult to determine the optimal combination of agents that promote Treg activity, while inhibiting Teff functions. Transient depletion of dividing $\mathrm{T}$ 
cells with anti-CD25 mAb altered the homeostatic balance and created space for de novo expansion of Tregs. Anti$\mathrm{CD} 25 \mathrm{mAb}$ recipients displayed tolerance to islet allografts, unlike control-treated recipients [128]. These data suggest that not all T-cell depleting therapies may have an effect on Tregs or that Tregs may adapt by downregulating CD25. In contrast, Li et al. showed that anti-CD25 mAb treatment prevented tolerance of liver allografts by reducing the ratio of $\mathrm{CD}^{+}{ }^{+} \mathrm{CD} 25^{+}$Tregs to $\mathrm{CD} 3^{+} \mathrm{T}$ cells [129]. The Teff/Treg ratio determines the outcome of the graft; therefore, expansion of Treg populations and deletion of effector T-cell populations are crucial to tolerance induction. Zheng et al. have shown that combined treatment of rapamycin and agonistic IL$2 / \mathrm{Fc}$ and antagonistic mutant IL-15/Fc selectively targeted alloreactive $\mathrm{T}$ cells while preserving Tregs [130]. When administered with other calcineurin inhibitors, beneficial effects were lost $[122,131,132]$. Thus, not all agents within a family necessarily exert the same effect.

One of the current limitations of Treg therapy is the inability to generate sufficient numbers of antigen-specific Tregs for therapeutic outcomes. The absence of reliable markers for human Tregs makes isolation and purification difficult. Isolated $\mathrm{T}$ cells would have to be expanded in vitro, but expansion may not be restricted to Treg populations specifically. Additionally, Tregs demonstrate a great degree of plasticity and have the potential of converting to an effector phenotype in vivo [133]. The risks associated with Treg therapy warrant further investigation and require technical advancement before application in humans.

\section{Organ Stromal Cells in Tolerance}

The contribution of organ stromal cells in the regulation of the immune response is understudied. Our group has extensively investigated the influence of these populations in the liver on islet transplantation. The liver is unique in that it is one of few organs with inherent tolerogenic properties [134-136]. A number of factors have been attributed to the tolerogenic state of liver allografts including increased Bcell infiltration, production of soluble MHC class I antigens, involvement from stromal cells, and presence of Tregs [112, 137-139]. The importance of liver stromal cells is highlighted by the fact that while liver transplantation in mice results in indefinite acceptance, transplantation of hepatocytes is rejected $[140,141]$.

We have focused on a population of stromal cells in the liver called the hepatic stellate cells (HSCs), which have been known to have a primary role in liver fibrosis and repair following hepatic injury. Additional features of these cells are their participation in the storage of vitamin A (retinoid) droplets, and their ability to produce TGF- $\beta$ in response to inflammation [142-144]. However, little is known about the involvement of HSCs in immune regulation. HSCs, from both mice and humans, have been shown to act as nonprofessional APCs and upregulate MHCs, CD40 and CD80, and inhibitory PD-L1, in response to proinflammatory cytokines $[137,139]$. Jiang et al. found that HSCs can also expand $\mathrm{CD}^{+} \mathrm{CD} 25^{+} \mathrm{Foxp}^{+}$cells in an IL-2-dependent manner
[145]. Therefore, it is conceivable that these cells possess tolerogenic qualities. Addition of HSCs into an MLR culture at an HSC to T ratio of $1: 20$ resulted in $80-90 \%$ inhibition of T-cell response [137]. In vivo inhibition was demonstrated in mice by cotransplantation of HSCs with islet allografts. A prolongation in survival in $>60 \%$ of islet allografts was observed without immunosuppression. This was associated with elimination of antigen-specific $\mathrm{T}$ cells and enhanced MDSC and Treg development [112, 146, 147]. It appears that HSCs exert their effects primarily by inducing MDSCs. The ability of HSCs to promote MDSCs was verified in vivo by analyses of mononucleocytes infiltrating the islet grafts. Cotransplantation with HSCs led to an accumulation of MDSCs, instead of DCs, as seen in islet alone grafts. In vitro evidence confirmed that addition of HSCs to BM-derived DC culture promoted the development of $\mathrm{CD} 11 \mathrm{~b}^{+} \mathrm{CD} 11^{-} \mathrm{c}$ cells displaying suppressive functions. MDSC induction was abolished in IFN- $\gamma^{-/}$recipients, demonstrating the additional dependency of an inflammatory environment for MDSC development $[112,146]$. MDSCs have been shown to induce Treg development as well [148]. Increased Treg levels were observed with islet/HSC transplantation. We, therefore, suspect that HSCs recruit MDSCs to the islet allografts and promote engraftment upon inflammation. Benten et al. have shown the tolerogenic role of HSCs in promoting hepatic engraftment in a rat hepatic allograft model. Hepatic transplantation led to the activation of HSCs and a series of genetic and phenotypic changes within the HSCs. Prior depletion of HSCs impaired hepatocyte acceptance [149]. HSCs demonstrate potent immunomodulatory properties and can influence the development of suppressor cells. With further study, HSCs may be implemented into tolerance inducing therapies.

Analogous to HSCs, Sertoli cells (SCs) within the seminiferous tubules of the testis also exhibit suppressive features. The immunoprivileged SCs have been exploited for protection of various transplanted tissues [150-154]. The immunoprotective capabilities of SCs can be extended across allogeneic and xenogeneic barriers $[155,156]$. Transplantation of SC xenografts alone into NOD mice altered the cytokine milieu in the pancreas and induced a regulatory environment, inhibiting IL-6, IL-10, and IFN- $\gamma$ production while promoting TGF- $\beta$ and the regulatory enzyme indoleamine. TGF- $\beta$ produced by the SCs was responsible for the generation of autoantigen-specific regulatory $\mathrm{T}$ cells. Recipients displayed reversion of diabetes with the SC xenografts [157]. It has also been shown that SCs have the ability to influence and inhibit T-cell responses and complement activation, although the mechanisms are not well defined [158-160]. Selawry et al. were the first group to demonstrate the application of the immunomodulatory SCs for inducing tolerance in islet transplantation [158, 161, 162]. Cotransplantation of SCs and islet allografts induced long-term graft survival, with recipients remaining normoglycemic for at least 60 days after transplantation without systemic immunosuppression [150, 157]. The transfer of xenogenic neonatal porcine SCs (NPSCs) at the time of islet transplantation was shown to prolong islet allograft survival in nonimmunosuppressed rats in a dose-dependent manner 
$(\mathrm{MST}=16.33 \pm 1.53$ days versus islets alone group, $5.67 \pm 0.94$ days). Examination of grafts showed reduced lymphocyte infiltration and increased expression of $\mathrm{Bcl}-2$ compared to recipients receiving islets alone, suggesting that NPSCs may also be regulating the expression of immunoprotective genes [163]. There is also evidence that NPSCs can suppress the upregulation of CD40 expression on DCs in response to LPS stimulation, thereby preventing full activation of the DCs and inducing the development of tolerogenic DCs [160]. The efficacy of NPSCs has even been demonstrated in human models of xenotransplantation. Transplantation of porcine islets and NPSCs into type 1 diabetic patients led to a reduction in insulin dependence and maintenance of metabolic control for up to 4 years without immunosuppression in half of the 12 patients involved in the study [164]. Cotransfer of SCs at the time of transplantation may, therefore, provide protection for alloislet transplants and improve chances of engraftment.

The BM also contains a rich source of immunomodulatory stromal cells referred to as mesenchymal stem cells (MSCs). MSCs have the capacity to develop into various types of mesodermal tissues and exhibit properties of selfrenewal [165]. MSCs alter the cytokine profile of DCs, naive and effector $\mathrm{T}$ cells, and $\mathrm{NK}$ cells in response to IFN- $\gamma$, downregulating the production of IFN- $\gamma$ and TNF- $\alpha$ in the microenvironment and inducing a more tolerogenic phenotype. IFN- $\gamma$-induced expression of the immunosuppressive factors TGF- $\beta$, hepatic growth factor (HGF), IL-10, prostaglandin E2, matrix metalloproteinases (MMPs), and IDO account for the inhibition of alloresponses [166-168]. Furthermore, MSCs were found to promote the expansion of Tregs [169-171]. Characterization of human MSCs has been a challenge, and the results are somewhat conflicting $[165,172]$. Fiorina et al. found that in their NOD model, murine bone-marrow-derived MSCs were positive for the stem cell markers CD29, CD44, CD73, CD105, and CD166 and negative for hematopoietic lineage markers CD45 and CD90.2 and costimulatory molecules CD40, CD80, and CD86. Interestingly, the MSCs expressed high levels of PD$\mathrm{L} 1$, and it was speculated that the level of PD-L1 expression enabled the immunosuppressive functions of MSCs [169].

The ability of MSCs to modulate T-cell responses and influence tissue rejection suggests a therapeutic role for inducing tolerance in islet transplantation. The negligible expression of MHC II and absence of costimulatory molecules on the cell surface allow MSCs to escape immune recognition. However, the immunomodulatory effects of MSCs observed in vitro have been difficult to replicate in vivo, as evidenced in baboon skin allograft and rat cardiac allograft models $[173,174]$. Allogeneic MSC infusion has been effective in preventing the onset of diabetes in prediabetic mice and reversing hyperglycemia in diabetic mice $[169,175]$. In islet transplantation models, MSCs demonstrate the ability to migrate to the pancreatic islets and exert an immunosuppressive effect in the graft microenvironment [176, 177]. MSCs have also been shown to influence pancreatic vascularization and remodeling following transplantation [178]. Although the mechanisms by which MSCs exert their immunosuppressive effects remain elusive, Ding et al. suggest that one possible strategy involves the production of MMP-2 and MMP-9. In culture, MSCs mediated T-cell proliferative arrest and hyporesponsiveness by downregulating CD25 on the surface of T cells. Downregulation of CD25 was dependent on the production of MMP-2 and MMP-9 by MSCs, since inhibition of MMP via the thiirane gelatinase inhibitor SB-3CT restored surface expression of CD25 and T-cell responses. Administration of syngeneic MSCs at the time of syngeneic islet transplantation prevented rejection in murine STZ-induced diabetic Rag- $2 / \gamma(\mathrm{c}) \mathrm{KO}$ recipients reconstituted with $\mathrm{CD} 4^{+} \mathrm{CD} 25^{-} \mathrm{T}$ cells and resulted in a rapid return to normoglycemia. In contrast, recipients under the same conditions treated with the MMP-2 and MMP-9 inhibitor SB-3CT became diabetic within 30 days (MST = 30 days) [167]. In theory, MSC therapies sound promising in the induction of tolerance but require further evaluation before clinical application.

\section{Concluding Remarks}

The future of islet transplantation depends on the development of tolerance inducing therapies. While temporary immunosuppression can be advantageous, the long-term risks outweigh the benefit. Tolerance suggests freedom from insulin dependency and an improvement in the patient's overall quality of life. A tolerizing regimen that utilizes techniques that selectively target donor-reactive $\mathrm{T}$ cells while expanding populations of regulatory $\mathrm{T}$ cells will result in better outcomes. Further investigation into inherently tolerogenic cells in the body such as HSCs, SCs, and MSCs will aid in the design of therapies. Though many challenges still remain, the progress made in the animal models of tolerance holds great promise for humans.

\section{References}

[1] Centers for Disease Control and Prevention, National Diabetes Fact Sheet: National Estimates and General Information on Diabetes and Prediabetes in the United States, U.S. Department of Health and Human Services, Centers for Disease Control and Prevention, Atlanta, Ga, USA, 2011.

[2] C. Ricordi and T. B. Strom, "Clinical islet transplantation: advances and immunological challenges," Nature Reviews Immunology, vol. 4, no. 4, pp. 259-268, 2004.

[3] P. Fiorina, A. M. J. Shapiro, C. Ricordi, and A. Secchi, "The clinical impact of islet transplantation," American Journal of Transplantation, vol. 8, no. 10, pp. 1990-1997, 2008.

[4] R. P. Robertson, "Islet transplantation as a treatment for diabetes-a work in progress," The New England Journal of Medicine, vol. 350, no. 7, pp. 694-705, 2004.

[5] P. W. Williams, "Notes on diabetes treated with extract andby grafts of sheep's pancreas," BMJ, vol. 2, pp. 1303-1304, 1894.

[6] C. B. Kemp, M. J. Knight, and D. W. Scharp, "Effect of transplantation site on the results of pancreatic islet isografts in diabetic rats," Diabetologia, vol. 9, no. 6, pp. 486-491, 1973.

[7] N. S. Kenyon, M. Chatzipetrou, M. Masetti et al., "Long-term survival and function of intrahepatic islet allografts in rhesus monkeys treated with humanized anti-CD154," Proceedings of the National Academy of Sciences of the United States of America, vol. 96, no. 14, pp. 8132-8137, 1999. 
[8] M. Hermann, R. Margreiter, and P. Hengster, "Human islet autotransplantation: the trail thus far and the highway ahead," in The Islets of Langerhans, M. S. Islam, Ed., vol. 654, pp. 711-724, Springer, Dordrecht, The Netherlands, 2010.

[9] C. Ricordi, P. E. Lacy, E. H. Finke, B. J. Olack, and D. W. Scharp, "Automated method for isolation of human pancreatic islets," Diabetes, vol. 37, no. 4, pp. 413-420, 1988.

[10] P. E. Lacy and M. Kostianovsky, "Method for the isolation of intact islets of Langerhans from the rat pancreas," Diabetes, vol. 16, no. 1, pp. 35-39, 1967.

[11] D. W. Scharp, P. E. Lacy, J. V. Santiago et al., "Insulin independence after islet transplantation into type I diabetic patient," Diabetes, vol. 39, no. 4, pp. 515-518, 1990.

[12] S. Merani and A. M. J. Shapiro, "Current status of pancreatic islet transplantation," Clinical Science, vol. 110, no. 6, pp. 611-625, 2006.

[13] E. Ingulli, "Mechanism of cellular rejection in transplantation," Pediatric Nephrology, vol. 25, no. 1, pp. 61-74, 2010.

[14] A. M. J. Shapiro, E. G. Hao, J. R. T. Lakey, D. T. Finegood, R. V. Rajotte, and N. M. Kneteman, "Defining optimal immunosuppression for islet transplantation based on reduced diabetogenicity in canine islet autografts," Transplantation, vol. 74, no. 11, pp. 1522-1528, 2002.

[15] A. M. J. Shapiro, J. R. T. Lakey, E. A. Ryan et al., "Islet transplantation in seven patients with type 1 diabetes mellitus using a glucocorticoid-free immunosuppressive regimen," The New England Journal of Medicine, vol. 343, no. 4, pp. 230238, 2000.

[16] E. A. Ryan, J. R. T. Lakey, R. V. Rajotte et al., "Clinical outcomes and insulin secretion after islet transplantation with the edmonton protocol," Diabetes, vol. 50, no. 4, pp. 710-719, 2001.

[17] P. Monti, M. Scirpoli, P. Maffi et al., "Islet transplantation in patients with autoimmune diabetes induces homeostatic cytokines that expand autoreactive memory T cells," The Journal of Clinical Investigation, vol. 118, no. 5, pp. 1806$1814,2008$.

[18] A. M. J. Shapiro, C. Ricordi, B. J. Hering et al., "International trial of the Edmonton protocol for islet transplantation," The New England Journal of Medicine, vol. 355, no. 13, pp. 1318 1330, 2006.

[19] R. Marcén, "Immunosuppressive drugs in kidney transplantation: impact on patient survival, and incidence of cardiovascular disease, malignancy and infection," Drugs, vol. 69, no. 16, pp. 2227-2243, 2009.

[20] J. Sprent and H. Kishimoto, "The thymus and central tolerance," Philosophical Transactions of the Royal Society B, vol. 356, no. 1409, pp. 609-616, 2001.

[21] O. O. Oluwole, H. A. Depaz, R. Gopinathan et al., "Indirect allorecognition in acquired thymic tolerance," Diabetes, vol. 50, no. 7, pp. 1546-1552, 2001.

[22] S. F. Oluwole, O. O. Oluwole, A. O. Adeyeri, and H. A. DePaz, "New strategies in immune tolerance induction," Cell Biochemistry and Biophysics, vol. 40, no. 3, pp. 27-48, 2004.

[23] L. D. Britt, D. W. Scharp, P. E. Lacy, and S. Slavin, "Transplantation of islet cells across major histocompatibility barriers after total lymphoid irradiation and infusion of allogeneic bone marrow cells," Diabetes, vol. 31, supplement 4, pp. 6368, 1982

[24] H. Li, C. L. Kaufman, S. S. Boggs, P. C. Johnson, K. D. Patrene, and S. T. Ildstad, "Mixed allogeneic chimerism induced by a sublethal approach prevents autoimmune diabetes and reverses insulitis in nonobese diabetic (NOD) mice," The Journal of Immunology, vol. 156, no. 1, pp. 380388, 1996.

[25] M. M. Horowitz, R. P. Gale, P. M. Sondel et al., "Graft-versusleukemia reactions after bone marrow transplantation," Blood, vol. 75, no. 3, pp. 555-562, 1990.

[26] M. Mielcarek, P. J. Martin, W. Leisenring et al., "Graft-versushost disease after nonmyeloablative versus conventional hematopoietic stem cell transplantation," Blood, vol. 102, no. 2, pp. 756-762, 2003.

[27] T. Wekerle, J. Kurtz, S. Bigenzahn, Y. Takeuchi, and M. Sykes, "Mechanisms of transplant tolerance induction using costimulatory blockade," Current Opinion in Immunology, vol. 14, no. 5, pp. 592-600, 2002.

[28] T. Wekerle, M. H. Sayegh, J. Hill et al., "Extrathymic T cell deletion and allogeneic stem cell engraftment induced with costimulatory blockade is followed by central $\mathrm{T}$ cell tolerance," Journal of Experimental Medicine, vol. 187, no. 12, pp. 2037-2044, 1998.

[29] T. Wekerle and M. Sykes, "Mixed chimerism and transplantation tolerance," Annual Review of Medicine, vol. 52, pp. 353370, 2001.

[30] B. Nikolic, Y. Takeuchi, I. Leykin, Y. Fudaba, R. N. Smith, and M. Sykes, "Mixed hematopoietic chimerism allows cure of autoimmune diabetes through allogeneic tolerance and reversal of autoimmunity," Diabetes, vol. 53, no. 2, pp. 376383, 2004.

[31] G. Elkin, T. B. Prighozina, O. Gurevitch, and S. Slavin, "Nonmyeloablative bone marrow transplantation based on deletion of host-anti-donor alloreactive cells prevents autoimmune insulitis and diabetes in nonobese diabetic mice," Transplantation Proceedings, vol. 34, no. 4, pp. 1303-1306, 2002.

[32] G. Elkin, T. B. Prigozhina, and S. Slavin, "Prevention of diabetes in nonobese diabetic mice by nonmyeloablative allogeneic bone marrow transplantation," Experimental Hematology, vol. 32, no. 6, pp. 579-584, 2004.

[33] L. Chatenoud and J. A. Bluestone, "CD3-specific antibodies: a portal to the treatment of autoimmunity," Nature Reviews Immunology, vol. 7, no. 8, pp. 622-632, 2007.

[34] L. Chatenoud, "CD3-specific antibody-induced active tolerance: from bench to bedside," Nature Reviews Immunology, vol. 3, no. 2, pp. 123-132, 2003.

[35] Y. Liang, T. Huang, C. Zhang et al., "Donor CD8 ${ }^{+}$T cells facilitate induction of chimerism and tolerance without GVHD in autoimmune NOD mice conditioned with antiCD3 mAb," Blood, vol. 105, no. 5, pp. 2180-2188, 2005.

[36] L. Chatenoud, E. Thervet, J. Primo, and J. F. Bach, "Anti-CD3 antibody induces long-term remission of overt autoimmunity in nonobese diabetic mice," Proceedings of the National Academy of Sciences of the United States of America, vol. 91, no. 1, pp. 123-127, 1994.

[37] M. Belghith, J. A. Bluestone, S. Barriot, J. Mégret, J. F. Bach, and L. Chatenoud, "TGF- $\beta$-dependent mechanisms mediate restoration of self-tolerance induced by antibodies to CD3 in overt autoimmune diabetes," Nature Medicine, vol. 9, no. 9, pp. 1202-1208, 2003.

[38] G. Chen, G. Han, J. Wang et al., "Essential roles of TGF- $\beta$ in anti-CD3 antibody therapy: reversal of diabetes in nonobese diabetic mice independent of $\mathrm{FoxP}^{+} \mathrm{CD}^{+}$regulatory $\mathrm{T}$ cells," Journal of Leukocyte Biology, vol. 83, no. 2, pp. 280-287, 2008.

[39] J. M. Thomas, J. L. Contreras, C. A. Smyth et al., "Successful reversal of streptozotocin-induced diabetes with stable 
allogeneic islet function in a preclinical model of type 1 diabetes," Diabetes, vol. 50, no. 6, pp. 1227-1236, 2001.

[40] B. J. Hering, R. Kandaswamy, J. D. Ansite et al., "Singledonor, marginal-dose islet transplantation in patients with type 1 diabetes," JAMA, vol. 293, no. 7, pp. 830-835, 2005.

[41] B. Hirshberg, K. I. Rother, B. J. Digon et al., "Benefits and risks of solitary islet transplantation for type 1 diabetes using steroid-sparing immunosuppression: the National Institutes of Health experience," Diabetes Care, vol. 26, no. 12, pp. 3288-3295, 2003.

[42] X. Préville, M. Flacher, B. LeMauff et al., "Mechanisms involved in antithymocyte globulin immunosuppressive activity in a nonhuman primate model," Transplantation, vol. 71, no. 3, pp. 460-468, 2001.

[43] E. A. Friedman and M. M. Beyer, "Effect of antithymocyte globulin on islet of Langerhans transplantation," Nephron, vol. 22, no. 1-3, pp. 212-216, 1978.

[44] C. Liu, H. Noorchashm, J. A. Sutter et al., "B lymphocytedirected immunotherapy promotes long-term islet allograft survival in nonhuman primates," Nature Medicine, vol. 13, no. 11, pp. 1295-1298, 2007.

[45] E. C. Guinan, J. G. Gribben, V. A. Boussiotis, G. J. Freeman, and L. M. Nadler, "Pivotal role of the B7:CD28 pathway in transplantation tolerance and tumor immunity," Blood, vol. 84, no. 10, pp. 3261-3282, 1994.

[46] T. C. Pearson, D. Z. Alexander, K. J. Winn, P. S. Linsley, R. P. Lowry, and C. P. Larsen, "Transplantation tolerance induced by CTLA4-Ig," Transplantation, vol. 57, no. 12, pp. 17011706, 1994.

[47] D. J. Lenschow, Y. Zeng, J. R. Thistlethwaite et al., "Longterm survival of xenogeneic pancreatic islet grafts induced by CTLA4Ig," Science, vol. 257, no. 5071, pp. 789-792, 1992.

[48] L. A. Turka, P. S. Linsley, H. Lin et al., "T-cell activation by the CD28 ligand B7 is required for cardiac allograft rejection in vivo," Proceedings of the National Academy of Sciences of the United States of America, vol. 89, no. 22, pp. 11102-11105, 1992.

[49] M. G. Levisetti, P. A. Padrid, G. L. Szot et al., "Immunosuppressive effects of human CTLA4Ig in a non-human primate model of allogeneic pancreatic islet transplantation," The Journal of Immunology, vol. 159, no. 11, pp. 5187-5191, 1997.

[50] T. M. Foy, A. Aruffo, J. Bajorath, J. E. Buhlmann, and R. J. Noelle, "Immune regulation by CD40 and its ligand GP39," Annual Review of Immunology, vol. 14, pp. 591-617, 1996.

[51] G. Van Kooten and J. Banchereau, "CD40-CD40 ligand," Journal of Leukocyte Biology, vol. 67, no. 1, pp. 2-17, 2000.

[52] D. C. Parker, D. L. Greiner, N. E. Phillips et al., "Survival of mouse pancreatic islet allografts in recipients treated with allogeneic small lymphocytes and antibody to CD40 ligand," Proceedings of the National Academy of Sciences of the United States of America, vol. 92, no. 21, pp. 9560-9564, 1995.

[53] N. S. Kenyon, L. A. Fernandez, R. Lehmann et al., "Longterm survival and function of intrahepatic islet allografts in baboons treated with humanized anti-CD154," Diabetes, vol. 48, no. 7, pp. 1473-1481, 1999.

[54] K. Shimizu, U. Schonbeck, F. Mach, P. Libby, and R. N. Mitchell, "Host CD40 ligand deficiency induces long-term allograft survival and donor-specific tolerance in mouse cardiac transplantation but does not prevent graft arteriosclerosis," The Journal of Immunology, vol. 165, no. 6, pp. 3506-3518, 2000.

[55] M. Koulmanda, R. N. Smith, A. Qipo, G. Weir, H. Auchincloss, and T. B. Strom, "Prolonged survival of allogeneic islets in cynomolgus monkeys after short-term anti-CD154-based therapy: nonimmunologic graft failure?" American Journal of Transplantation, vol. 6, no. 4, pp. 687-696, 2006.

[56] N. N. Iwakoshi, J. P. Mordes, T. G. Markees, N. E. Phillips, A. A. Rossini, and D. L. Greiner, "Treatment of allograft recipients with donor-specific transfusion and anti-CD154 antibody leads to deletion of alloreactive $\mathrm{CD}^{+} \mathrm{T}$ cells and prolonged graft survival in a CTLA4-dependent manner," The Journal of Immunology, vol. 164, no. 1, pp. 512-521, 2000.

[57] M. M. Durham, A. W. Bingaman, A. B. Adams et al., "Cutting edge: administration of anti-CD40 ligand and donor bone marrow leads to hemopoietic chimerism and donor-specific tolerance without cytoreductive conditioning," The Journal of Immunology, vol. 165, no. 1, pp. 1-4, 2000.

[58] A. D. Kirk, D. M. Harlan, N. N. Armstrong et al., "CTLA4Ig and anti-CD40 ligand prevent renal allograft rejection in primates," Proceedings of the National Academy of Sciences of the United States of America, vol. 94, no. 16, pp. 8789-8794, 1997.

[59] A. M. Azimzadeh, S. Pfeiffer, G. Wu et al., "Alloimmunity in primate heart recipients with CD154 blockade: evidence for alternative costimulation mechanisms," Transplantation, vol. 81, no. 2, pp. 255-264, 2006.

[60] I. Koyama, T. Kawai, D. Andrews et al., "Thrombophilia associated with anti-CD154 monoclonal antibody treatment and its prophylaxis in nonhuman primates," Transplantation, vol. 77, no. 3, pp. 460-462, 2004.

[61] C. Van Kooten, G. Lombardi, K. A. Gelderman et al., "Dendritic cells as a tool to induce transplantation tolerance: obstacles and opportunities," Transplantation, vol. 91, no. 1, pp. 2-7, 2011.

[62] L. Lu and A. W. Thomson, "Genetic engineering of dendritic cells to enhance their tolerogenic potential," Graft, vol. 5, no. 5, pp. 308-314, 2002.

[63] K. Shortman and Y. J. Liu, "Mouse and human dendritic cell subtypes," Nature Reviews Immunology, vol. 2, no. 3, pp. 151161, 2002.

[64] J. I. Youn, S. Nagaraj, M. Collazo, and D. I. Gabrilovich, "Subsets of myeloid-derived suppressor cells in tumorbearing mice," The Journal of Immunology, vol. 181, no. 8, pp. 5791-5802, 2008.

[65] A. W. Thomson, L. Lu, N. Murase, A. J. Demetris, A. S. Rao, and T. E. Starzl, "Microchimerism, dendritic cell progenitors and transplantation tolerance," Stem Cells, vol. 13, no. 6, pp. 622-639, 1995.

[66] H. R. Christensen, H. Frøkiær, and J. J. Pestka, "Lactobacilli differentially modulate expression of cytokines and maturation surface markers in murine dendritic cells," The Journal of Immunology, vol. 168, no. 1, pp. 171-178, 2002.

[67] M. Li, X. Zhang, X. Zheng et al., "Tolerogenic dendritic cells transferring hyporesponsiveness and synergizing $\mathrm{T}$ regulatory cells in transplant tolerance," International Immunology, vol. 20, no. 2, pp. 285-293, 2008.

[68] M. M. Tiao, L. Lu, R. Tao, L. Wang, J. J. Fung, and S. Qian, "Prolongation of cardiac allograft survival by systemic administration of immature recipient dendritic cells deficient in NF- $\kappa$ B activity," Annals of Surgery, vol. 241, no. 3, pp. 497505, 2005.

[69] X. Luo, K. V. Tarbell, H. Yang et al., "Dendritic cells with TGF- $\beta 1$ differentiate naïve CD ${ }^{+}$CD25- T cells into isletprotective Foxp $3^{+}$regulatory T cells," Proceedings of the $\mathrm{Na}$ tional Academy of Sciences of the United States of America, vol. 104, no. 8, pp. 2821-2826, 2007. 
[70] D. H. Munn, M. D. Sharma, B. Baban et al., "GCN2 kinase in $\mathrm{T}$ cells mediates proliferative arrest and anergy induction in response to indoleamine 2,3-dioxygenase," Immunity, vol. 22, no. 5, pp. 633-642, 2005.

[71] N. Sonenberg, J. W. B. Hershey, and M. B. Mathews, Translational Control of Gene Expression, CSHL Press, 2001.

[72] J. C. Ochando, C. Homma, Y. Yang et al., "Alloantigen-presenting plasmacytoid dendritic cells mediate tolerance to vascularized grafts," Nature Immunology, vol. 7, no. 6, pp. 652$662,2006$.

[73] M. F. Mackey, J. R. Gunn, C. Maliszewski, H. Kikutani, R. J. Noelle, and R. J. Barth, "Cutting edge: dendritic cells require maturation via CD40 to generate protective antitumor immunity," The Journal of Immunology, vol. 161, no. 5, pp. 2094-2098, 1998.

[74] T. De Smedt, M. Van Mechelen, G. De Becker, J. Urbain, O. Leo, and M. Moser, "Effect of interleukin-10 on dendritic cell maturation and function," European Journal of Immunology, vol. 27, no. 5, pp. 1229-1235, 1997.

[75] M. B. Lutz, R. M. Suri, M. Niimi et al., "Immature dendritic cells generated with low doses of GM-CSF in the absence of IL-4 are maturation resistant and prolong allograft survival in vivo," European Journal of Immunology, vol. 30, no. 7, pp. 1813-1822, 2000.

[76] K. Inaba, M. Inaba, N. Romani et al., "Generation of large numbers of dendritic cells from mouse bone marrow cultures supplemented with granulocyte/macrophage colonystimulating factor," Journal of Experimental Medicine, vol. 176, no. 6, pp. 1693-1702, 1992.

[77] K. Garrigan, P. Moroni-Rawson, C. McMurray et al., "Functional comparison of spleen dendritic cells and dendritic cells cultured in vitro from bone marrow precursors," Blood, vol. 88, no. 9, pp. 3508-3512, 1996.

[78] H. R. Turnquist, G. Raimondi, A. F. Zahorchak, R. T. Fischer, Z. Wang, and A. W. Thomson, "Rapamycin-conditioned dendritic cells are poor stimulators of allogeneic $\mathrm{CD}^{+} \mathrm{T}$ cells, but enrich for antigen-specific Foxp $3^{+}$T regulatory cells and promote organ transplant tolerance," The Journal of Immunology, vol. 178, no. 11, pp. 7018-7031, 2007.

[79] L. Ma, S. Qian, X. Liang et al., "Prevention of diabetes in NOD mice by administration of dendritic cells deficient in nuclear transcription factor- $\kappa$ B activity," Diabetes, vol. 52 , no. 8, pp. 1976-1985, 2003.

[80] C. A. Bonham, L. Peng, X. Liang et al., "Marked prolongation of cardiac allograft survival by dendritic cells genetically engineered with NF- $\kappa \mathrm{B}$ oligodeoxyribonucleotide decoys and adenoviral vectors encoding CTLA4-Ig," The Journal of Immunology, vol. 169, no. 6, pp. 3382-3391, 2002.

[81] W. P. Min, R. Gorczynski, X. Y. Huang et al., "Dendritic cells genetically engineered to express Fas ligand induce donorspecific hyporesponsiveness and prolong allograft survival," The Journal of Immunology, vol. 164, no. 1, pp. 161-167, 2000.

[82] L. Lu, W. C. Lee, T. Takayama et al., "Genetic engineering of dendritic cells to express immunosuppressive molecules (viral IL-10, TGF- $\beta$, and CTLA4Ig)," Journal of Leukocyte Biology, vol. 66, no. 2, pp. 293-296, 1999.

[83] L. Lu, A. Gambotto, W. C. Lee et al., "Adenoviral delivery of CTLA4lg into myeloid dendritic cells promotes their in vitro tolerogenicity and survival in allogeneic recipients," Gene Therapy, vol. 6, no. 4, pp. 554-563, 1999.

[84] B. Almand, J. I. Clark, E. Nikitina et al., "Increased production of immature myeloid cells in cancer patients: a mechanism of immunosuppression in cancer," The Journal of Immunology, vol. 166, no. 1, pp. 678-689, 2001.

[85] C. M. Diaz-Montero, M. L. Salem, M. I. Nishimura, E. Garrett-Mayer, D. J. Cole, and A. J. Montero, "Increased circulating myeloid-derived suppressor cells correlate with clinical cancer stage, metastatic tumor burden, and doxorubicin-cyclophosphamide chemotherapy," Cancer Immunology, Immunotherapy, vol. 58, no. 1, pp. 49-59, 2009.

[86] E. Peranzoni, S. Zilio, I. Marigo et al., "Myeloid-derived suppressor cell heterogeneity and subset definition," Current Opinion in Immunology, vol. 22, no. 2, pp. 238-244, 2010.

[87] D. I. Gabrilovich and S. Nagaraj, "Myeloid-derived suppressor cells as regulators of the immune system," Nature Reviews Immunology, vol. 9, no. 3, pp. 162-174, 2009.

[88] S. Kusmartsev, Y. Nefedova, D. Yoder, and D. I. Gabrilovich, "Antigen-Specific Inhibition of $\mathrm{CD}^{+} \mathrm{T}$ Cell Response by Immature Myeloid Cells in Cancer Is Mediated by Reactive Oxygen Species," The Journal of Immunology, vol. 172, no. 2, pp. 989-999, 2004.

[89] V. Bronte and P. Zanovello, "Regulation of immune responses by L-arginine metabolism," Nature Reviews Immunology, vol. 5, no. 8, pp. 641-654, 2005.

[90] B. Zhu, Y. Bando, S. Xiao et al., "CD11b ${ }^{+}$Ly-6Chi suppressive monocytes in experimental autoimmune encephalomyelitis," The Journal of Immunology, vol. 179, no. 8, pp. 5228-5237, 2007.

[91] D. Ilkovitch and D. M. Lopez, "Immune modulation by melanoma-derived factors," Experimental Dermatology, vol. 17, no. 12, pp. 977-985, 2008.

[92] V. Greifenberg, E. Ribechini, S. Rößner, and M. B. Lutz, "Myeloid-derived suppressor cell activation by combined LPS and IFN- $\gamma$ treatment impairs DC development," European Journal of Immunology, vol. 39, no. 10, pp. 2865-2876, 2009.

[93] V. Bronte, "Myeloid-derived suppressor cells in inflammation: uncovering cell subsets with enhanced immunosuppressive functions," European Journal of Immunology, vol. 39, no. 10, pp. 2670-2672, 2009.

[94] P. Serafini, R. Carbley, K. A. Noonan, G. Tan, V. Bronte, and I. Borrello, "High-dose granulocyte-macrophage colonystimulating factor-producing vaccines impair the immune response through the recruitment of myeloid suppressor cells," Cancer Research, vol. 64, no. 17, pp. 6337-6343, 2004.

[95] D. Gabrilovich, T. Ishida, T. Oyama et al., "Vascular endothelial growth factor inhibits the development of dendritic cells and dramatically affects the differentiation of multiple hematopoietic lineages in vivo," Blood, vol. 92, no. 11, pp. 41504166, 1998.

[96] S. K. Bunt, P. Sinha, V. K. Clements, J. Leips, and S. OstrandRosenberg, "Inflammation induces myeloid-derived suppressor cells that facilitate tumor progression," The Journal of Immunology, vol. 176, no. 1, pp. 284-290, 2006.

[97] S. K. Bunt, L. Yang, P. Sinha, V. K. Clements, J. Leips, and S. Ostrand-Rosenberg, "Reduced inflammation in the tumor microenvironment delays the accumulation of myeloid-derived suppressor cells and limits tumor progression," Cancer Research, vol. 67, no. 20, pp. 10019-10026, 2007.

[98] X. Song, Y. Krelin, T. Dvorkin et al., "CD11b+/Gr-1+ immature myeloid cells mediate suppression of $\mathrm{T}$ cells in mice bearing tumors of IL- $1 \beta$-secreting cells," The Journal of Immunology, vol. 175, no. 12, pp. 8200-8208, 2005.

[99] S. Nagaraj and D. I. Gabrilovich, "Tumor escape mechanism governed by myeloid-derived suppressor cells," Cancer Research, vol. 68, no. 8, pp. 2561-2563, 2008. 
[100] J. G. Cripps and J. D. Gorham, "MDSC in autoimmunity," International Immunopharmacology, vol. 11, no. 7, pp. 789793, 2011.

[101] J. A. Van Ginderachter, A. Beschin, P. De Baetselier, and G. Raes, "Myeloid-derived suppressor cells in parasitic infections," European Journal of Immunology, vol. 40, no. 11, pp. 2976-2985, 2010.

[102] P. C. Rodriguez, A. H. Zea, K. S. Culotta, J. Zabaleta, and J. B. Ochoa Augusto C Ochoa, "Regulation of T cell receptor $\mathrm{CD} 3 \zeta$ chain expression by L-arginine," The Journal of Biological Chemistry, vol. 277, no. 24, pp. 21123-21129, 2002.

[103] K. J. Peyton, D. Ensenat, M. A. Azam et al., "Arginase promotes neointima formation in rat injured carotid arteries," Arteriosclerosis, Thrombosis, and Vascular Biology, vol. 29, no. 4, pp. 488-494, 2009.

[104] R. M. Bingisser, P. A. Tilbrook, P. G. Holt, and U. R. Kees, "Macrophage-derived nitric oxide regulates $\mathrm{T}$ cell activation via reversible disruption of the Jak3/STAT5 signaling pathway," The Journal of Immunology, vol. 160, no. 12, pp. 5729 $5734,1998$.

[105] O. Harari and J. K. Liao, "Inhibition of MHC II gene transcription by nitric oxide and antioxidants," Current Pharmaceutical Design, vol. 10, no. 8, pp. 893-898, 2004.

[106] H. T. Chung, H. O. Pae, B. M. Choi, T. R. Billiar, and Y. M. Kim, "Breakthroughs and views: nitric oxide as a bioregulator of apoptosis," Biochemical and Biophysical Research Communications, vol. 282, no. 5, pp. 1075-1079, 2001.

[107] S. Nagaraj, K. Gupta, V. Pisarev et al., "Altered recognition of antigen is a mechanism of CD8 ${ }^{+} \mathrm{T}$ cell tolerance in cancer," Nature Medicine, vol. 13, no. 7, pp. 828-835, 2007.

[108] S. Ostrand-Rosenberg and P. Sinha, "Myeloid-derived suppressor cells: linking inflammation and cancer," The Journal of Immunology, vol. 182, no. 8, pp. 4499-4506, 2009.

[109] A. S. Dugast, T. Haudebourg, F. Coulon et al., "Myeloidderived suppressor cells accumulate in kidney allograft tolerance and specifically suppress effector t cell expansion," The Journal of Immunology, vol. 180, no. 12, pp. 7898-7906, 2008.

[110] V. De Wilde, N. Van Rompaey, M. Hill et al., "Endotoxininduced myeloid-derived suppressor cells inhibit alloimmune responses via heme oxygenase-1," American Journal of Transplantation, vol. 9, no. 9, pp. 2034-2047, 2009.

[111] H.-S. Chou, C.-C. Hsieh, R. Charles et al., "Myeloid-derived suppressor cells protect islet transplants by b7-h1 mediated enhancement of T regulatory cells," Transplantation, vol. 93, no. 3, pp. 272-282, 2012.

[112] H. S. Chou, C. C. Hsieh, H. R. Yang et al., "Hepatic stellate cells regulate immune response by way of induction of myeloid suppressor cells in mice," Hepatology, vol. 53, no. 3, pp. 1007-1019, 2011.

[113] D. Golshayan, J. C. Wyss, C. W. Abulker et al., “Transplantation tolerance induced by regulatory $\mathrm{T}$ cells: in vivo mechanisms and sites of action," International Immunopharmacology, vol. 9, no. 6, pp. 683-688, 2009.

[114] D. Golshayan, S. Jiang, J. Tsang, M. I. Garin, C. Mottet, and R. I. Lechler, "In vitro-expanded donor alloantigen-specific $\mathrm{CD} 4{ }^{+} \mathrm{CD} 25^{+}$regulatory $\mathrm{T}$ cells promote experimental transplantation tolerance," Blood, vol. 109, no. 2, pp. 827-835, 2007.

[115] L. Graca, S. P. Cobbold, and H. Waldmann, "Identification of regulatory T cells in tolerated allografts," Journal of Experimental Medicine, vol. 195, no. 12, pp. 1641-1646, 2002.

[116] S. Jiang, Ed., Regulatory T Cells and Clinical Application, Springer, New York, NY, USA, 2009.
[117] S. Z. Josefowicz and A. Rudensky, "Control of regulatory T cell lineage commitment and maintenance," Immunity, vol. 30, no. 5, pp. 616-625, 2009.

[118] C. A. Piccirillo, E. d'Hennezel, E. Sgouroudis, and E. Yurchenko, "CD4 ${ }^{+}$Foxp $3^{+}$regulatory $\mathrm{T}$ cells in the control of autoimmunity: in vivo veritas," Current Opinion in Immunology, vol. 20, no. 6, pp. 655-662, 2008.

[119] J. Carreras, A. Lopez-Guillermo, B. C. Fox et al., "High numbers of tumor-infiltrating FOXP3-positive regulatory $\mathrm{T}$ cells are associated with improved overall survival in follicular lymphoma," Blood, vol. 108, no. 9, pp. 2957-2964, 2006.

[120] Y. Li, X. Zhao, D. Cheng et al., "The presence of Foxp3 expressing T cells within grafts of tolerant human liver transplant recipients," Transplantation, vol. 86, no. 12, pp. 18371843, 2008.

[121] S. Spoerl and X. C. Li, "Regulatory T cells and the quest for transplant tolerance," Discovery Medicine, vol. 11, no. 56, pp. 25-34, 2011.

[122] M. Noris, F. Casiraghi, M. Todeschini et al., "Regulatory T cells and T cell depletion: role of immunosuppressive drugs," Journal of the American Society of Nephrology, vol. 18, no. 3, pp. 1007-1018, 2007.

[123] A. Maeda, A. Schwarz, K. Kernebeck et al., "Intravenous infusion of syngeneic apoptotic cells by photopheresis induces antigen-specific regulatory T cells," The Journal of Immunology, vol. 174, no. 10, pp. 5968-5976, 2005.

[124] Z. Wang, A. T. Larregina, W. J. Shufesky et al., "Use of the inhibitory effect of apoptotic cells on dendritic cells for graft survival via T-cell deletion and regulatory T cells," American Journal of Transplantation, vol. 6, no. 6, pp. 1297-1311, 2006.

[125] S. Sakaguchi, T. Yamaguchi, T. Nomura, and M. Ono, "Regulatory T cells and immune tolerance," Cell, vol. 133, no. 5, pp. 775-787, 2008.

[126] P. T. Walsh, D. K. Taylor, and L. A. Turka, "Tregs and transplantation tolerance," The Journal of Clinical Investigation, vol. 114, no. 10, pp. 1398-1403, 2004.

[127] N. Zhang, B. Schröppel, G. Lal et al., "Regulatory T cells sequentially migrate from inflamed tissues to draining lymph nodes to suppress the alloimmune response," Immunity, vol. 30, no. 3, pp. 458-469, 2009.

[128] S. Giraud, B. Barrou, S. Sebillaud, P. Debré, D. Klatzmann, and V. Thomas-Vaslin, "Transient depletion of dividing T lymphocytes in mice induces the emergence of regulatory T cells and dominant tolerance to islet allografts," American Journal of Transplantation, vol. 8, no. 5, pp. 942-953, 2008.

[129] W. Li, K. Carper, Y. Liang et al., "Anti-CD25 mAb administration prevents spontaneous liver transplant tolerance," Transplantation Proceedings, vol. 38, no. 10, pp. 3207-3208, 2006.

[130] X. X. Zheng, A. Sánchez-Fueyo, M. Sho, C. Domenig, M. H. Sayegh, and T. B. Strom, "Favorably tipping the balance between cytopathic and regulatory $\mathrm{T}$ cells to create transplantation tolerance," Immunity, vol. 19, no. 4, pp. 503-514, 2003.

[131] D. S. Segundo, J. C. Ruiz, M. Izquierdo et al., "Calcineurin inhibitors, but not rapamycin, reduce percentages of $\mathrm{CD} 4{ }^{+} \mathrm{CD} 25^{+} \mathrm{Foxp}^{+}$regulatory $\mathrm{T}$ cells in renal transplant recipients," Transplantation, vol. 82, no. 4, pp. 550-557, 2006.

[132] J. J. A. Coenen, H. J. P. M. Koenen, E. van Rijssen et al., "Rapamycin, not cyclosporine, permits thymic generation and peripheral preservation of $\mathrm{CD} 4{ }^{+} \mathrm{CD} 25^{+} \mathrm{FoxP} 3^{+} \mathrm{T}$ cells," Bone Marrow Transplantation, vol. 39, no. 9, pp. 537-545, 2007. 
[133] J. L. Riley, C. H. June, and B. R. Blazar, "Human T regulatory cell therapy: take a billion or so and call me in the morning," Immunity, vol. 30, no. 5, pp. 656-665, 2009.

[134] B. Dresske, X. Lin, D. S. Huang, X. Zhou, and F. Fändrich, "Spontaneous tolerance: experience with the rat liver transplant model," Human Immunology, vol. 63, no. 10, pp. 853861, 2002.

[135] I. N. Crispe, M. Giannandrea, I. Klein, B. John, B. Sampson, and S. Wuensch, "Cellular and molecular mechanisms of liver tolerance," Immunological Reviews, vol. 213, no. 1, pp. 101-118, 2006.

[136] G. Tiegs and A. W. Lohse, "Immune tolerance: what is unique about the liver," Journal of Autoimmunity, vol. 34, no. 1, pp. $1-6,2010$.

[137] M. C. Yu, C. H. Chen, X. Liang et al., "Inhibition of T-cell responses by hepatic stellate cells via B7-H1-mediated T-cell apoptosis in mice," Hepatology, vol. 40, no. 6, pp. 1312-1321, 2004.

[138] Q. You, L. Cheng, R. M. Kedl, and C. Ju, "Mechanism of T cell tolerance induction by murine hepatic Kupffer cells," Hepatology, vol. 48, no. 3, pp. 978-990, 2008.

[139] M. Morita, M. Fujino, G. Jiang et al., "PD-1/B7-H1 interaction contribute to the spontaneous acceptance of mouse liver allograft," American Journal of Transplantation, vol. 10, no. 1, pp. 40-46, 2010.

[140] G. L. Bumgardner, D. Gao, J. Li, J. H. Baskin, M. Heininger, and C. G. Orosz, "Rejection responses to allogeneic hepatocytes by reconstituted SCID mice, CD4 KO, and CD8 KO mice1,2," Transplantation, vol. 70, no. 12, pp. 1771-1780, 2000.

[141] G. L. Bumgardner and C. G. Orosz, "Unusual patterns of alloimmunity evoked by allogeneic liver parenchymal cells," Immunological Reviews, vol. 174, pp. 260-279, 2000.

[142] A. Geerts, "History, heterogeneity, developmental biology, and functions of quiescent hepatic stellate cells," Seminars in Liver Disease, vol. 21, no. 3, pp. 311-335, 2001.

[143] H. Senoo, "Structure and function of hepatic stellate cells," Medical Electron Microscopy, vol. 37, no. 1, pp. 3-15, 2004.

[144] M. Sato, S. Suzuki, and H. Senoo, "Hepatic stellate cells: unique characteristics in cell biology and phenotype," Cell Structure and Function, vol. 28, no. 2, pp. 105-112, 2003.

[145] G. Jiang, H. R. Yang, L. Wang et al., "Hepatic stellate cells preferentially expand allogeneic $\mathrm{CD} 4{ }^{+} \mathrm{CD} 25^{+} \mathrm{FoxP} 3{ }^{+}$regulatory $\mathrm{T}$ cells in an IL-2-dependent manner," Transplantation, vol. 86, no. 11, pp. 1492-1502, 2008.

[146] H. R. Yang, H. S. Chou, X. Gu et al., "Mechanistic insights into immunomodulation by hepatic stellate cells in mice: a critical role of interferon- $\gamma$ signaling," Hepatology, vol. 50, no. 6, pp. 1981-1991, 2009.

[147] C. H. Chen, L. M. Kuo, Y. Chang et al., "In vivo immune modulatory activity of hepatic stellate cells in mice," Hepatology, vol. 44, no. 5, pp. 1171-1181, 2006.

[148] B. Huang, P. Y. Pan, Q. Li et al., "Gr- $1^{+} \mathrm{CD} 115^{+}$immature myeloid suppressor cells mediate the development of tumorinduced $\mathrm{T}$ regulatory cells and $\mathrm{T}$-cell anergy in tumorbearing host," Cancer Research, vol. 66, no. 2, pp. 1123-1131, 2006.

[149] D. Benten, V. Kumaran, B. Joseph et al., "Hepatocyte transplantation activates hepatic stellate cells with beneficial modulation of cell engraftment in the rat," Hepatology, vol. 42, no. 5, pp. 1072-1081, 2005.

[150] W. Suarez-Pinzon, G. S. Korbutt, R. Power, J. Hooton, R. V. Rajotte, and A. Rabinovitch, "Testicular Sertoli cells protect islet $\beta$-cells from autoimmune destruction in NOD mice by a transforming growth factor- $\beta 1$-dependent mechanism," Diabetes, vol. 49, no. 11, pp. 1810-1818, 2000.

[151] H. Yang and J. R. Wright, "Co-encapsulation of sertoli enriched testicular cell fractions further prolongs fish-to-mouse islet xenograft survival," Transplantation, vol. 67, no. 6, pp. 815-820, 1999.

[152] D. F. Emerich, R. Hemendinger, and C. R. Halberstadt, "The testicular-derived sertoli cell: cellular immunoscience to enable transplantation," Cell Transplantation, vol. 12, no. 4, pp. 335-349, 2003.

[153] C. Halberstadt, D. F. Emerich, and P. Gores, "Use of Sertoli cell transplants to provide local immunoprotection for tissue grafts," Expert Opinion on Biological Therapy, vol. 4, no. 6, pp. 813-825, 2004.

[154] G. S. Korbutt, J. F. Elliott, and R. V. Rajotte, "Cotransplantation of allogeneic islets with allogeneic testicular cell aggregates allows long-term graft survival without systemic immunosuppression," Diabetes, vol. 46, no. 2, pp. 317-322, 1997.

[155] P. Mital, G. Kaur, and J. M. Dufour, "Immunoprotective Sertoli cells: making allogeneic and xenogeneic transplantation feasible," Reproduction, vol. 139, no. 3, pp. 495-504, 2010.

[156] Q. A. Ramji, K. Bayrack, H. Arefanian et al., "Protection of porcine islet xenografts in mice using sertoli cells and monoclonal antibodies," Transplantation, vol. 92, no. 12, pp. 1309-1315, 2011.

[157] F. Fallarino, G. Luca, M. Calvitti et al., "Therapy of experimental type 1 diabetes by isolated Sertoli cell xenografts alone," Journal of Experimental Medicine, vol. 206, no. 11, pp. 2511-2526, 2009.

[158] H. P. Selawry and D. F. Cameron, "Sertoli cell-enriched fractions in successful islet cell transplantation," Cell Transplantation, vol. 2, no. 2, pp. 123-129, 1993.

[159] P. De Cesaris, A. Filippini, C. Cervelli et al., "Immunosuppressive molecules produced by Sertoli cells cultured in vitro: biological effects on lymphocytes," Biochemical and Biophysical Research Communications, vol. 186, no. 3, pp. 1639-1646, 1992.

[160] H. M. Lee, C. O. Byoung, D. P. Lim et al., "Mechanism of humoral and cellular immune modulation provided by porcine Sertoli cells," Journal of Korean Medical Science, vol. 23, no. 3, pp. 514-520, 2008.

[161] H. P. Selawry and K. Whittington, "Extended allograft survival of islets grafted into intra-abdominally placed testis," Diabetes, vol. 33, no. 4, pp. 405-406, 1984.

[162] H. P. Selawry and K. B. Whittington, "Prolonged intratesticular islet allograft survival in not dependent on local steroidogenesis," Hormone and Metabolic Research, vol. 20, no. 9, pp. 562-565, 1988.

[163] Z. Yin, D. Chen, F. Hu et al., "Cotransplantation with xenogenetic neonatal porcine Sertoli cells significantly prolongs islet allograft survival in nonimmunosuppressive rats," Transplantation, vol. 88, no. 3, pp. 339-345, 2009.

[164] R. A. Valdés-González, L. M. Dorantes, G. N. Garibay et al., "Xenotransplantation of porcine neonatal islets of Langerhans and Sertoli cells: a 4-year study," European Journal of Endocrinology, vol. 153, no. 3, pp. 419-427, 2005.

[165] M. F. Pittenger, A. M. Mackay, S. C. Beck et al., "Multilineage potential of adult human mesenchymal stem cells," Science, vol. 284, no. 5411, pp. 143-147, 1999.

[166] S. Aggarwal and M. F. Pittenger, "Human mesenchymal stem cells modulate allogeneic immune cell responses," Blood, vol. 105, no. 4, pp. 1815-1822, 2005. 
[167] Y. Ding, D. Xu, G. Feng, A. Bushell, R. J. Muschel, and K. J. Wood, "Mesenchymal stem cells prevent the rejection of fully allogenic islet grafts by the immunosuppressive activity of matrix metalloproteinase-2 and -9," Diabetes, vol. 58, no. 8, pp. 1797-1806, 2009.

[168] J. M. Ryan, F. P. Barry, J. M. Murphy, and B. P. Mahon, "Mesenchymal stem cells avoid allogeneic rejection," Journal of Inflammation, vol. 2, no. 1, article 8, 2005.

[169] P. Fiorina, M. Jurewicz, A. Augello et al., "Immunomodulatory function of bone marrow-derived mesenchymal stem cells in experimental autoimmune type 1 diabetes," The Journal of Immunology, vol. 183, no. 2, pp. 993-1004, 2009.

[170] F. Casiraghi, N. Azzollini, P. Cassis et al., "Pretransplant infusion of mesenchymal stem cells prolongs the survival of a semiallogeneic heart transplant through the generation of regulatory T cells," The Journal of Immunology, vol. 181, no. 6, pp. 3933-3946, 2008.

[171] D. M. Berman, M. A. Willman, D. Han et al., "Mesenchymal stem cells enhance allogeneic islet engraftment in nonhuman primates," Diabetes, vol. 59, no. 10, pp. 2558-2568, 2010.

[172] D. Baksh, L. Song, and R. S. Tuan, "Adult mesenchymal stem cells: characterization, differentiation, and application in cell and gene therapy," Journal of Cellular and Molecular Medicine, vol. 8, no. 3, pp. 301-316, 2004.

[173] A. Bartholomew, C. Sturgeon, M. Siatskas et al., "Mesenchymal stem cells suppress lymphocyte proliferation in vitro and prolong skin graft survival in vivo," Experimental Hematology, vol. 30, no. 1, pp. 42-48, 2002.

[174] S. Inoue, F. C. Popp, G. E. Koehl et al., "Immunomodulatory effects of mesenchymal stem cells in a rat organ transplant model," Transplantation, vol. 81, no. 11, pp. 1589-1595, 2006.

[175] F. E. Ezquer, M. E. Ezquer, D. B. Parrau, D. Carpio, A. J. Yañez, and P. A. Conget, "Systemic administration of multipotent mesenchymal stromal cells reverts hyperglycemia and prevents nephropathy in type 1 diabetic mice," Biology of Blood and Marrow Transplantation, vol. 14, no. 6, pp. 631640, 2008.

[176] V. Sordi, M. L. Malosio, F. Marchesi et al., "Bone marrow mesenchymal stem cells express a restricted set of functionally active chemokine receptors capable of promoting migration to pancreatic islets," Blood, vol. 106, no. 2, pp. 419427, 2005.

[177] V. Sordi, R. Melzi, A. Mercalli et al., "Mesenchymal cells appearing in pancreatic tissue culture are bone marrowderived stem cells with the capacity to improve transplanted islet function," Stem Cells, vol. 28, no. 1, pp. 140-151, 2010.

[178] C. L. Rackham, P. C. Chagastelles, N. B. Nardi, A. C. HaugeEvans, P. M. Jones, and A. J. F. King, "Co-transplantation of mesenchymal stem cells maintains islet organisation and morphology in mice," Diabetologia, vol. 54, no. 5, pp. 1127$1135,2011$. 


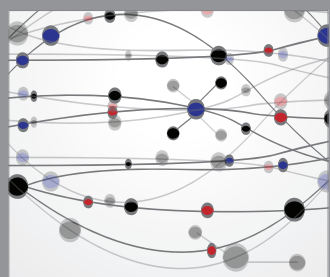

The Scientific World Journal
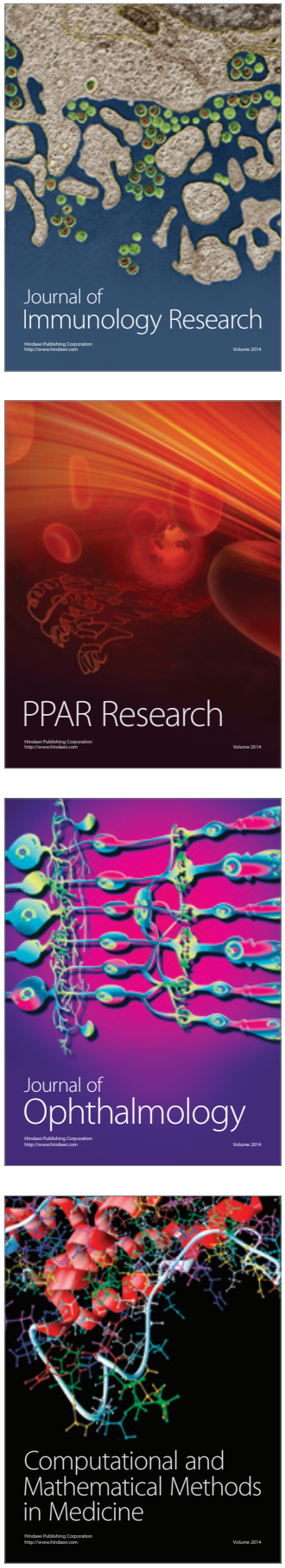

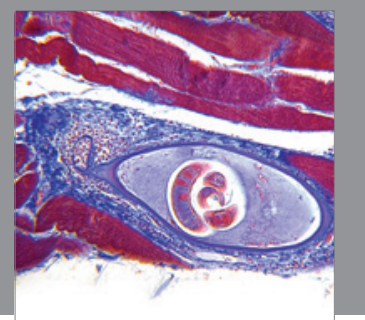

Gastroenterology

Research and Practice
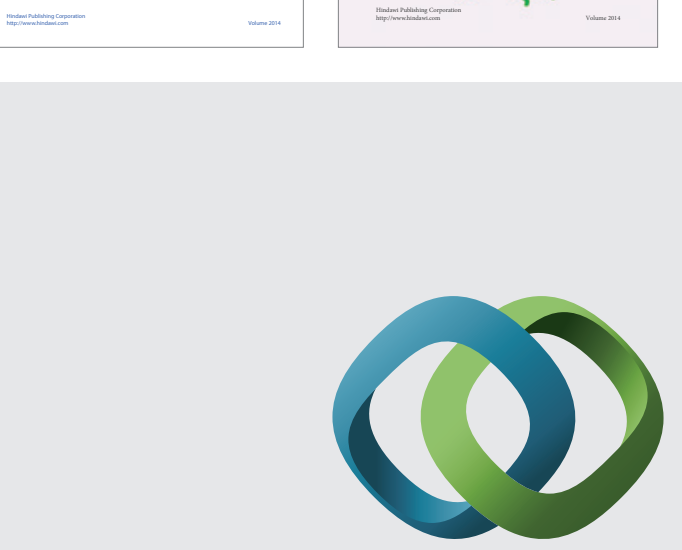

\section{Hindawi}

Submit your manuscripts at

http://www.hindawi.com
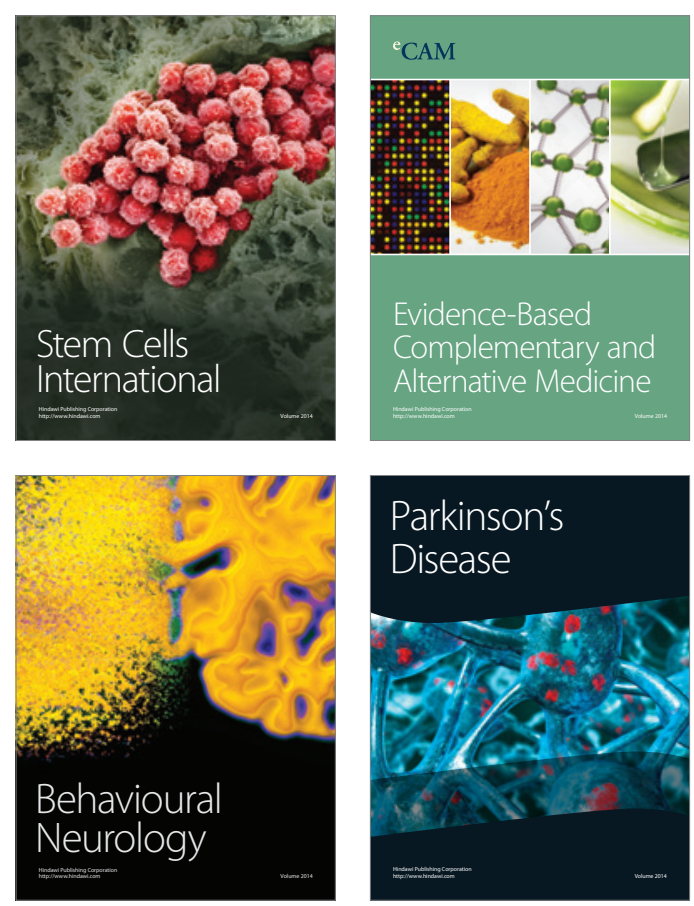

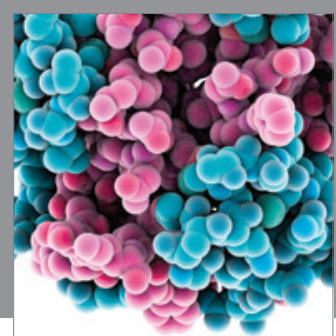

Journal of
Diabetes Research

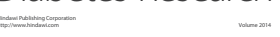

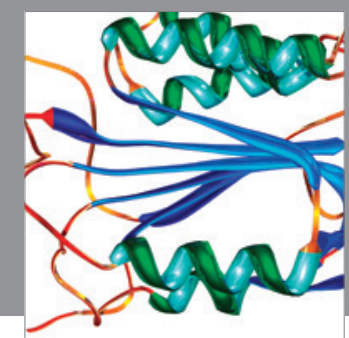

Disease Markers
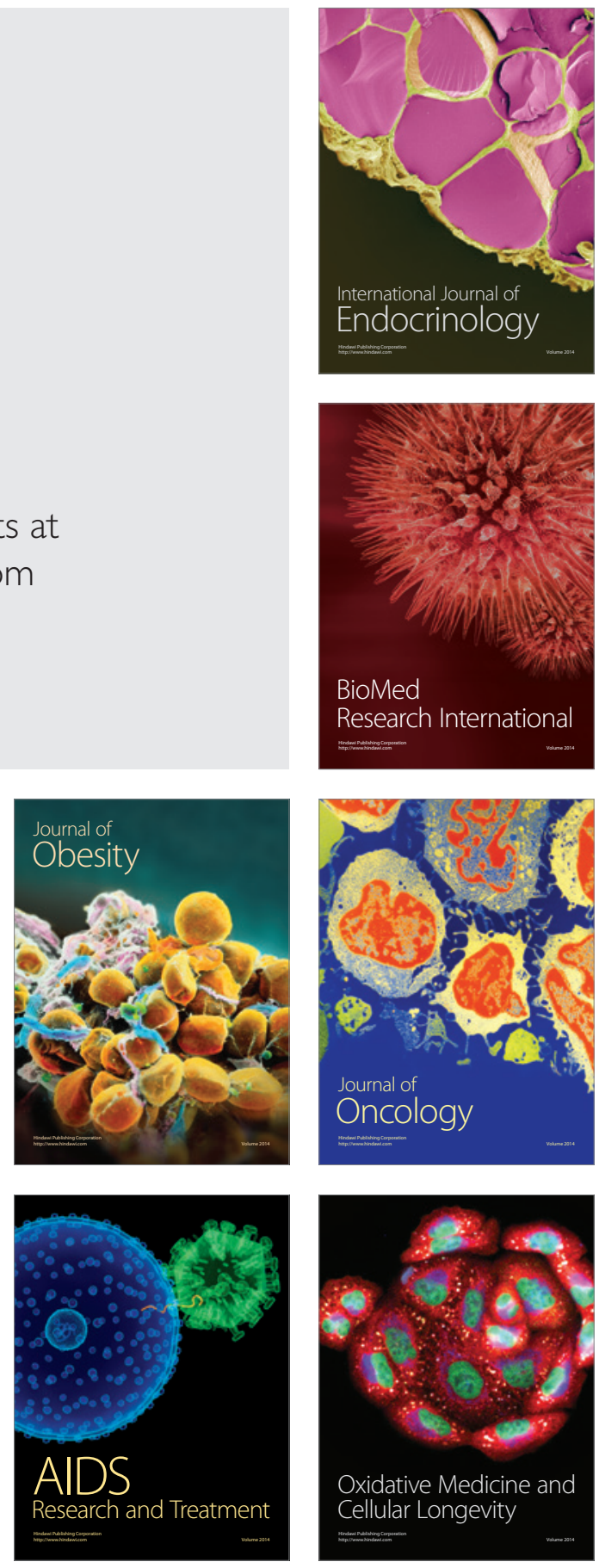